\title{
Ethical Conundrums Facing Mediators: Comparing Processes, Identifying Challenges and Opportunities
}

\author{
Judy Gutman and Jodie Grant*
}

\begin{abstract}
Mediation forms a core part of dispute resolution initiatives in family law and civil litigation. This article considers several ethical issues confronting mediators in family and civil disputes. We compare ethical frameworks, drawing on issues arising from mediation practice in two specific court-connected fora. Further, we make recommendations for changes to existing mediator training and to applicable standards and codes.
\end{abstract}

\section{INTRODUCTION}

The last two decades have witnessed the rapid and sustained growth and institutionalisation of ADR and mediation in particular. ${ }^{1}$ Boulle adopts a useful 'models' framework describing various mediation practices. ${ }^{2}$ The wide-ranging application of mediation fosters a 'diversity' in practice, ${ }^{3}$ allowing for wide discretion to be exercised by mediators. ${ }^{4}$

* This article draws on and develops themes explored elsewhere, and draws on previous publications by the author(s). The authors are mediators with clinical experience in the areas of practice which form the basis of this article.

1 Joe Harman, 'From Alternative to Primary Dispute Resolution: The pivotal role of mediation in (and in avoiding) litigation' (Speech delivered at National Mediation Conference, Melbourne, Australia 2014) 7. The now defunct National Alternative Dispute Resolution Advisory Council (NADRAC) outlines ADR processes in Australia and, while not intended to be exhaustive, the description revealed the widespread use of ADR processes in a variety of contexts: community dispute resolution; family mediation services; courts and tribunals; statutory agencies; industry schemes; public policy dispute resolution; commercial ADR; and internal organisation ADR. The range of examples referred to above is indicative of the prevalence of $\mathrm{ADR}$ and mediation and also the varied nature of their use. The term mediation is used throughout this article. We use the word to refer to classic mediation processes as described by Folberg and Taylor as a process ' $[b]$ y which the participants, together with the assistance of a neutral person or persons, systematically isolate disputed issues in order to develop options, consider alternatives, and reach a consensual settlement that will accommodate their needs'. See Jay Folberg and Alison Taylor Mediation: A Comprehensive Guide to Resolving Conflicts without Giving In (Jossey-Bass, 1988).

2 Lawrence Boulle, Mediation: Principles, Practices, Process (Lexis Nexis, 3rd ed, 2011) 43-48.

3 Ibid 404

4 See Bobette Wolski, 'The "New" Limitations of Fisher and Ury's Model of Interest-Based Negotiation: Not Necessarily the Ethical Alternative' (2012) 19 James Cook University Law Review 127, 154-155, citing Julie MacFarlane, 'Mediating Ethically: The Limits of Codes of Conduct and the Potential of a 
The entrenched and accepted nature of ADR processes such as mediation within Australian courts is indisputable ${ }^{5}$ leading to the 'vanishing trial' phenomenon. ${ }^{6}$ Disputants are diverted from determinative processes to mediation.

The rise of mediation suggests 'a deep disenchantment with the traditional, confrontational techniques that are inherent in the common law adversarial system'. ${ }^{7}$ Processes include court-connected mediation in the Magistrates' Court and Family Dispute Resolution (FDR) ${ }^{8}$ which is mediation translated into a specific family law context. ${ }^{9}$ The term of art, FDR underscores both the primacy of the process in family law disputing, and also how mainstream the process has become in the family dispute resolution milieu. ${ }^{10}$

The 'gold standard' of ethical mediation practice derives from the classic facilitative model of mediation. ${ }^{11}$ The mediation processes explored in this article purport to ascribe to this orthodox paradigm of mediation. However, we question whether this is in fact so. If it is not so, what are the resultant ethical implications, and how can and should they be addressed and managed by regulators and trainers?

Reflective Practice Model' (2002) 40 Osgoode Hall Law Journal 49, 65: Charles Pou Jr, "Embracing Limbo": Thinking About Rethinking Dispute Resolution Ethics' (2003-2004) 108 Pennsylvania State Law Review 1 in support of the proposition.

$5 \quad$ For examples of State, Federal and Tribunal systems that institutionalise ADR in Australia, see Tania Sourdin, Alternative Dispute Resolution (Lawbook Co, 5th ed, 2016) 295-330.

6 For example, David Spencer, 'The Phenomenon of the Vanishing Civil Trial' (2005) 8(2) Australian Alternative Dispute Resolution Bulletin 1, 2.

$7 \quad$ Arie Freiberg, 'Post-Adversarial and Post-Inquisitorial Justice: Transcending Traditional Penological Paradigms' (2011) 8 European Journal of Criminology 82, 83.

8 Family Law Act 1975 (Cth) s 10F (FLA) defines FDR as 'a process (other than a judicial process) ... in which a family dispute resolution practitioner helps people ... to resolve some or all of their disputes with each other; and in which the practitioner is independent of all of the parties involved in the process'.

9 Sourdin, above n 5, 107.

10 See Family Dispute Resolution Australian Government Attorney General's Department <www.ag.gov.au/FamiliesAndMarriage/Families/ FamilyDisputeResolution/Pages/default.aspx >: 'The law requires separating families who have a dispute about children to make a genuine effort to try to sort it out through family dispute resolution (FDR) before filing an application for parenting orders in court. This requirement applies to anyone wanting to file an application with a family law court. It also includes those seeking changes to an existing parenting order. Unless an exemption applies, parties seeking to have a parenting matter determined by a family law court will need to file a certificate from an accredited FDR practitioner. The certificate is issued under s 60I of the Family Law Act 1975 (Cth) and is commonly known as a s 60I Certificate.'

11 Rachael Field, 'Mediation Ethics in Australia - A Case for Rethinking the Foundational Paradigm' (2012) 19 James Cook University Law Review 41, 42. See $\mathrm{n} 1$ above for the Folberg and Taylor definition of mediation. 
Waldman identified that the growth and various uses and contexts of mediation lead to a range of mediator practices. ${ }^{12}$ The central thesis of this article is that the model of mediation practice is influenced by the professional background of the mediator, the context in which mediation occurs, the shadow cast by the legal system, and the ethical framework of the practitioner.

We contend that the nature of the dispute and its forum inform the process and have different impacts on the ethics of practice, posing 'vexing question[s]'. ${ }^{13}$

The article is in seven parts. In Part II we describe the processes. Part III considers points of difference and similarities in the processes. Part IV examines ethical viewpoints and contexts. In Parts V-VIII we discuss a range of ethical tensions including issues posed by the privatisation of justice, compulsory participation, nexus with the court system and the pressure to settle. We conclude by acknowledging that several ethical conundrums remain problematic for mediators. We make future-focussed recommendations.

\section{The Processes}

Mediation arose in the context of community and neighbourhood disputes, ${ }^{14}$ outside formal justice processes, and away from courts and litigation. ${ }^{15}$ Whilst mediation developed as a user-friendly, informal, voluntary, cooperative model for dispute resolution, growing social trends, including no fault divorce and different forms of family relationships rendered existing legal frameworks unsatisfactory to deal with the social constructs of many disputes. ${ }^{16}$

The civil claims mediation program (the Program) of the Dispute Settlement Centre of Victoria (DSCV), is a free dispute resolution service funded by the Victorian Government. It provides mediation services, as well as training and accrediting mediators to national standards. ${ }^{17}$

The Program provides a mediation service at several Magistrates' Courts in metropolitan Melbourne and Victorian regional locations. ${ }^{18}$ Case

12 See Ellen A Waldman, 'Identifying the Role of Social Norms in Mediation: A Multiple Model Approach' (1996-1997) Hastings Law Journal 703.

13 Mary Anne Noone and Lola Akin Ojelabi 'Ethical Challenges for Mediators around the Globe: An Australian Perspective' (2014) 45 Washington University Journal of Law \& Policy 145, 145.

14 See Hilary Astor and Christine Chinkin, Dispute Resolution in Australia (Butterworths, 2nd ed, 2002) 10, 14.

15 Harman, above $\mathrm{n} 1$.

16 See William Felstiner, Richard Abel and Austin Sarat, 'The Emergence and Transformation of Disputes; Naming, Blaming, Claiming' (1980-1) 15 (3-4) Law and Society Review 631.

17 See Dispute Settlement Centre of Victoria, About $U s<$ www.disputes.vic.gov.au/ about-us>.

18 For defended civil claims under $\$ 40,000$. The service also provides mediation for civil disputes to a monetary value capped at the jurisdictional limit of the 
management results are positive. The number of matters going to trial has reduced, thereby decreasing court waiting lists. The Program boasts an 85 per cent resolution statistic, meaning that the litigants reach agreement during mediation. The matter is not set down for trial and does not proceed to a hearing before a Magistrate. ${ }^{19}$

The Program is branded 'facilitative'. ${ }^{20}$ However, anecdotal evidence suggests that the practice model closely resembles the settlement mediation paradigm described by Boulle. ${ }^{21}$ Mediators encourage parties to compromise by engaging in 'incremental bargaining'. ${ }^{22}$ The shadow of the law, including the exercise of wide judicial discretion in decision making is often used as a mediator tool to encourage parties to settle. ${ }^{23}$ Mediators often refer to the expense and vagaries of a contested hearing to promote agreement. ${ }^{24}$

Secondly, we examine FDR practitioner ethics in family law matters at Relationships Australia Victoria (RAV) ${ }^{25}$ RAV is a community-based, not-for-profit organisation offering specialist family and relationship services and programs including counselling, FDR, mediation services, and specialised group and support services. ${ }^{26}$

FDR practitioners operate within a legislative framework. Harman argues that the Family Law Act 1975 (Cth) (FLA) does not use the terms mediation or mediator. ${ }^{27} \mathrm{He}$ acknowledges and accepts that FDR and mediation are one and the same, the difference lying in nomenclature alone. ${ }^{28}$

FDR acts as an entry point to the family law system for parenting matters,$^{29}$ highlighting how the Australian government prioritises a

Magistrates' Court of Victoria $(\$ 100,000)$ that are referred to mediation by a Court pursuant to Magistrates' Court Act 1989 (Vic) s 108.

19 See Dispute Settlement Centre of Victoria, above n 17.

20 Ibid.

21 Boulle, Mediation, above n 2, 44-45.

22 Adele Carr, 'Broadening the traditional use of mediation to resolve interlocutory issues arising in matters before the courts' (2016) 27 Australasian Dispute Resolution Journal 10.

23 Laurence Boulle, 'Law and Mediation: Conflict or Coalescence?' (1996) 2 Commercial Dispute Resolution Journal 173.

24 Although no empirical data exists to support the statements, the article is based on anecdotal evidence provided by experienced practitioners.

25 FDR practitioners are specialist mediators and work under the Family Law system with couples and families who are separating. They mediate parenting, property and financial disputes, see Attorney-General's Department, Family Dispute Resolution <www.ag.gov.au/FamiliesAndMarriage/Families/ FamilyDisputeResolution/Pages/default.aspx $>$.

26 RAV provides training - vocational training and professional development in a range of areas relating to direct service provision as well as training and accrediting FDR Practitioners and mediators to national standards.

27 Joe Harman, 'Should Mediation be the First Step in All Family Law Act Proceedings?' (2016) 27 Australasian Dispute Resolution Journal 17.

28 Ibid 17.

29 FDR operates separately from and independently to the Family Court and Federal Circuit Court. 
cultural change from litigation to one of cooperation for separating families. The focus is on the needs of child(ren), and assisting parents to meet their child(ren)'s best interests. We argue that FDR is influenced more by the 'helping professions' than by legalism. Our view is that FDR is best described as facilitative mediation. However, drawing on Boulle's models, FDR can be more aligned to a transformative model of mediation. ${ }^{30}$

We conclude this part by noting that mediation is a term that covers a range of practices. ${ }^{31}$ Despite the different process characteristics inherent in various models, Boulle states that there is a 'standard mediation process'. ${ }^{32}$ Further, mediation frameworks are often 'aspirational'. ${ }^{33}$ They seek to mimic the classic model of mediation. Yet, the reality of practice does not always match with purist desires.

\section{Similarities ANd Differences}

Both FDR and civil mediation have some common traits. Both processes focus on 'managing the docket' because case management drives much of the court annexed efficiency agenda. ${ }^{34}$ Court backlogs are assisted by matters settling before a hearing at mediation. ${ }^{35}$ The approaches also value the needs and interests of people and endeavour to repair relationships and prevent conflict, rather than emphasise who is right or wrong. ${ }^{36}$ They seek to promote a consensus-based approach, aspiring to encourage open and respectful communication ${ }^{37}$ and striving to achieve 'connection rather than separation'. ${ }^{38}$ Both processes 'are built on a premise that seeks to harness the "rights plus" potential of law and law's inherent ability to act as an agent for constructive change, both for individuals and the community'. ${ }^{39}$

However, process distinctions exist. FDR is a 'Pre-action Procedure'. ${ }^{40}$ It is the first step in FLA proceedings, ${ }^{41}$ thereby potentially setting a

$30 \quad$ Boulle, above n 2, 44-45.

31 Ibid.

32 Ibid 223.

33 Ibid.

34 This position has been judicially endorsed: see the joint judgment in Aon Risk Services Australia v Australian National University (2009) 258 ALR 14.

35 Carr, above n 22, 12.

36 Susan Daicoff, 'Making the Law Therapeutic for Lawyers: Therapeutic Jurisprudence, Preventive Law, and the Psychology of Lawyers' (1999) 5 Psychology, Public Policy, and Law 811, 826.

37 Susan Douglas, 'Humanising Legal Education: Lessons from ADR' (2012) 23 Alternative Dispute Resolution Journal 216, 222.

38 R Fisher, W Ury and B Patton, Getting to Yes: Negotiating an Agreement Without Giving In (Random House Business Books, 2nd ed, 1997) cited in Just Balstad, 'What Do Litigants Want? Comparing and Evaluating Adversarial Negotiation and ADR' (2005) 16 Alternative Dispute Resolution Journal 244, 245.

39 Susan Daicoff, 'Law as a Healing Profession: The Comprehensive Law Movement' (2006) 6 Pepperdine Dispute Resolution Law Journal 1, 4.

40 See Family Law Rules 2004 (Cth) Part 1.2 Sch 1.

41 Harman, above n 27, 18. 
non-adversarial tone that promotes collaboration and interest-based problem solving. By contrast, mediations in the Magistrates' Court civil list take place after a complaint has been filed with the Court. Often, other pleadings have been lodged and discovery has also taken place. Mediation occurs when disruptors of collaboration may have taken hold. The procedural pathway to a contested hearing of a civil dispute is paved by adversarial enhancers. ${ }^{42}$ This notwithstanding, others have expressed concern that early mediation where parties have incomplete and imperfect information can lead to unfair bases for agreement. ${ }^{43}$

Another difference is that FDR is often multidisciplinary, rather than legally-focussed. ${ }^{44} \mathrm{FDR}$ may draw on affiliated services that support families in dispute, such as counselling, specialist family violence, and parenting order programs to assist high conflict separating families. Practitioners require advanced skills to adequately prepare parties in cases of family violence.

FDR underscores how mediation spearheads a community-based interface, broadening the justice system from court-based processes to $\mathrm{ADR}^{45}$ and an umbrella of community-focused strategies. ${ }^{46}$ Yet, although Field calls for a safe model for family mediation, advocating for the Coordinated Family Dispute Resolution model, which has been positively evaluated, the Model has not been implemented at the time of writing. ${ }^{47}$

By contrast, civil mediations take place in the deep shadow of the law'. ${ }^{48}$ Mediations are totally connected to the litigation process. Significantly, Boulle asserts that the procedural conditions of immersion into adversarialism ingrains similar values into the mediation. ${ }^{49}$

We now move from a discussion of processes, distinctions and similarities to ensuing ethical concerns.

\section{Ethical Frameworks and Models of Practice}

We explore two questions in this part of the article. First, how can mediators maintain that the process they are conducting is 'mediation' when

42 See the Joint Judgment of the High Court of Australia in Aon Risk Services Australia v Australian National University (2009) 258 ALR 14.

43 See Leonie Wood, 'Early mediation one-sided, says judge', Sydney Morning Herald (Sydney), 1 December 2010, referring to the remarks of Justice Ray Finkelstein expressing concern about early mediation leading to injustice where one side has not received all relevant information.

44 Freiberg, above n 7, 86.

45 Michael King et al, Non-Adversarial Justice (Federation Press, 2009) 13.

46 Family Relationships Online, About Family Relationship Centres <www.familyrelationships.gov.au/services/frc/pages/default.aspx>; Family Court of Australia $<$ www.familycourt.gov.au/wps/wcm/connect/fcoaweb/home>; Family Court Australia, Reaching an agreement without going to court, <www.familycourt. gov.au/wps/wcm/connect/fcoaweb/family-law-matters/family-dispute-resolution>.

47 Rachel Field, ‘A Call for a Safe Model of Family Mediation' (2016) 28 (1) Bond Law Review 83.

48 Boulle, above n 2, 144.

49 Ibid 144. 
that process deviates from classical iterations of mediation? Second, how can mediators come to terms with deficiencies in the model of mediation that they practice?

In civil disputes, a settlement and to a lesser extent facilitative framework underscores processes, practitioner roles, techniques and practices. An existential ethical tension that may arise for mediators in the civil claims mediation program is whether they are conducting mediation at all. Bush and Folger categorise the civil claims program process as a 'settlement conference' which, in their view, compromises a 'central and supreme' value of mediation - self-determination. ${ }^{50}$ How does a mediator in this context come to terms with the following conflict of interest and conflict of duty? On the one hand, a mediator is ethically committed to advance party choice - although it is recognised that party choice may be constrained by a complicated web of factors, such as education, gender, ethnicity, personality, and psycho-social and economic factors. On the other hand, there is mediator knowledge of the shadow cast by the law (and perhaps some substantive and procedural expertise in the subject area), mediator responsibilities to ease the civil court backlog and mediator dedication to advance the administration of faster, cheaper and more efficient justice.

Whilst we acknowledge the diversity of practice within FDR, we argue that these conundrums also reverberate through FDR, where a facilitative and transformative framework focuses on a didactic approach emphasising children's best interests. This approach can however, shift into a settlement focus. Processes are subject to individual practitioner skill and discretion. If one views mediator discretion as being beneficial because it is useful in targeting party interests, how can risks be mitigated?

Whilst this raises the opportunity for individualised services with outcomes that are arguably tailored and appropriate to each family (hopefully increasing the likelihood of outcomes that are durable, sustainable, liveable and safe), it simultaneously raises questions around risk and consistency. Do FDR clients receive very different services? Are clients able to make informed choices about the service they will receive? We note that Brown et al conclude that there is a lack of literature relating to FDR services due to a variety of factors falling outside the scope of this article. ${ }^{51}$

FDR practitioners face additional tensions: how to prioritise party self-determination and empowerment juxtaposed against being advisory; balancing practitioner impartiality and neutrality against confidentiality and potential perceptions around being an agent of the court; how to remain neutral as an advisor; balancing managing power dynamics and

50 Robert A Baruch Bush and Joseph P Folger, Reclaiming Mediation's Future: Getting Over the Intoxication of Expertise, Re-Focusing on Party Self-Determination (November 2014) Mediate.com <www.mediate.com/articles/BushFolgerFuture. cfm\#>.

51 Thea Brown, Becky Batagol and Tania Sourdin, 'Family Support Program Literature Review, Research into Family Support Program: Family Law Services' (Research Report, Australian Centre for Justice Innovation, 12 January 2012). 
enhancing capacity to participate; dealing with collusion and non-disclosure; and parties being willing and prepared to make agreements that are less than fair and may not be in their interests. These ethical dilemmas can create a tightrope effect and require practitioner self-awareness, insight and reflection - all within an individualised, situational and private process.

Mediators who conduct civil disputes in the Magistrates' Court require National Accreditation under the Mediator Standards Board. This is an established National Mediator Accreditation System (NMAS) setting out Approval Standards and Practice Standards around process and ethical principles. ${ }^{52}$ Practice Standard 8 prescribes ethical conduct and professional relations. Requirements include competence, not to act for personal gain, adherence to mediator's professional ethical code, debriefing, courtesy, professional support and liaison, consideration of vulnerable stakeholders. Practice Standard 9 sets out confidentiality expectations, and Practice Standard 7 contains duties aimed at attaining fair, equitable and unbiased mediation processes. ${ }^{53}$

Many mediators who work at the Program have law degrees and they are also legal practitioners. ${ }^{54}$ This means that the model of mediation practice delivered in the Program is informed by standards and guidelines that address the conduct and professional obligations of lawyer mediators. ${ }^{55}$ Lawyer mediators are bound by core duties to the court. ${ }^{56}$ And, importantly, the legislative regime governing lawyers' professional conduct and ethics covers mediation. ${ }^{57}$ Lawyers are ethically bound to obey the law, advance honesty, integrity, efficiency and equity in the administration of justice. ${ }^{58}$

FDR practitioners come from prescribed primary backgrounds such as psychology, social work, law and conflict management. ${ }^{59}$ They are required

52 See Mediator Standards Board, The Standards <www.msb.org.au/ mediator-standards/standards $>$.

53 Ibid.

54 The proposition is derived from anecdotal evidence as at the time of writing, there is a lack of empirical data.

55 See Law Council of Australia, Ethical Guidelines for Mediators (August 2011) $<$ www.lawcouncil.asn.au/FEDLIT/images/Ethical_guidelines_for_mediators. pdf>. See also Mary Anne Noone, 'Lawyers as Mediators: More Responsibility?' (2006) 17 Australian Dispute Resolution Journal 1.

56 See Legal Profession Uniform Law Australian Solicitors' Conduct Rules 2015 (Vic) rr 17-29.

57 See Legal Profession Uniform Law Australian Solicitors' Conduct Rules 2015 (Vic) Glossary of Terms, meaning of 'court'.

58 See Legal Profession Uniform Law Australian Solicitors' Conduct Rules 2015 (Vic) rr 3 and 4.

59 The Commonwealth Attorney General's department manages the accreditation of FDR practitioners in Australia. The Family Law legislative framework sets out criteria for practice, process, and accreditation relating to qualifications and competencies. This legislative instrument references the Australian Qualifications Framework and required training. 
to "uphold reasonable professional standards in the provision of family dispute resolution services' ${ }^{\prime 60}$ and work within the legislative framework. ${ }^{61}$

Nevertheless, FDR practitioner's core background and personal value system impact on their delivery of these services. Practitioners operate in a framework of systemised reflective practice and supervision processes that actively facilitate self-awareness beginning from training and continuing throughout practice. Additionally, FDR practice is often rooted in community organisations and surrounded by a therapeutic culture which is committed to supervision processes that encourage reflective practice.

Leering describes the essential components of reflective practice as critical reflection, self-reflection, integrative reflection, and community centred reflection. ${ }^{62}$ In civil disputes mediation there is a process of debriefing, yet there is no training element or practice standard that targets the requirement of reflective practice within a supervisory environment. There is no clear, discipline-specific process for evaluating or reviewing performance which calls for case analysis and practitioner competencies, including ethical awareness. Such deficiencies may present ethical concerns for mediators. We call for a Standard requiring reflective practice to be inserted as a Mediation Practice Standard and a focused and appropriate alteration to the training regime. ${ }^{63}$ The additions may promote both ethical insight and a process of continuous learning by mediators. Reflective practice may also assist in the development of a professional community of mediators practising as an ethical group. ${ }^{64}$

\section{Private and Confidential Justice}

FDR processes are confidential within limits. ${ }^{65}$ Similarly, civil mediations are conducted confidentially, as far as the law allows. ${ }^{66}$ Confidentiality has long been both a hallmark and also a perceived positive of mediation processes. ${ }^{67}$ Parties are more likely to uncover interests by full and frank

60 Family Law (Family Dispute Resolution Practitioners) Regulations (Cth) r 15.

61 Oyiela Litaba 'Developing Ethical Practice as a Family Dispute Resolution Practitioner' (2013) 24 Australasian Dispute Resolution Journal 36.

62 Michele Leering 'Conceptualizing Reflective Practice for Legal Professionals' (2014) 23 Journal of Law and Social Policy 23.

63 See Samantha Hardy and Olivia Rundle, 'Applying the Inclusive Model of Ethical Decision Making to Mediation’ (2012) 19 James Cook University Law Review 70. See also Donald A Schön, The Reflective Practitioner: How Professionals Think in Action (Basic Books, New York, 1983) for a seminal discussion of reflective practice.

64 See Jonathan Crowe, 'Ethics and the Mediation Community' (2015) 26 Australasian Dispute Resolution Journal 20.

65 See Family Law Act 1975 (Cth) ss 10H, $19 \mathrm{~N}$.

66 The legislative bases and relevant processes are set out in Magistrates' Court Act 1989 (Vic), s 3; Magistrates' Court General Civil Procedure Rules 2010 (Vic) r 22A.02; Civil Procedure Act 2010 (Vic) ss 3, 66-67.

67 Rachael Field and Neal Wood, 'Marketing Mediation Ethically: The Case of Confidentiality' (2005) 5(2) Queensland University of Technology Law and Justice Journal 143, 147; Sourdin, above n 5, 479. 
disclosure if they have no concerns about confidentiality 'in the room'. ${ }^{68}$ If party expectations are not met, the integrity of the process will most certainly be jeopardized. Mediator standards generally require mediators to maintain the confidentiality of the process, as required by the parties. ${ }^{69}$ This notwithstanding, several authors agree that the extent and nature of confidentiality in mediations is somewhat unsettled - confidentiality is not a concrete notion. It is a fluid concept. ${ }^{70}$

In addition, statutory provisions seek to deal with the exclusion of evidence of settlement negotiations. ${ }^{71}$ Because the legislation applies differently depending on whether mediation occurs before or after court proceedings are instituted, the current status quo is hard to navigate. Furthermore, some authors argue that the breadth of legislative exceptions exacerbates uncertainty and confusion in regards to admissibility. ${ }^{72}$

As FDR processes occur within the private sphere and in community settings, they are often not open to scrutiny or review. FDR practitioners may have concerns about the information provided in FDR that is not disclosed within legal processes. This has given rise to challenges around confidentiality and potential disclosure around risk. ${ }^{73}$ At present, FDR practitioners may feel that both the process and they, themselves, are ethically compromised by disclosures of this type.

Altobelli and Bryant present confidentiality as a serious ethical conundrum for FDR practitioners for several reasons. First, existing confidentiality rules may not serve the child. Further, tensions arise between maintaining confidentiality in FDR and allowing the Court to have all available evidence, especially in cases of family violence and abuse. $^{74}$

Part V highlights the ethical challenges that arise in mediation practice in the context of adhering to the primary mediation principle that the mediation room provides an environment where parties can disclose information without worrying that disclosures will be publicised and used against them at a later time.

68 See, for example, the High Court of Australia joint judgment nearly 60 years ago in Field $v$ Commissioner of Railways (NSW) (1957) 99 CLR 285. See also Field and Wood, above $\mathrm{n} 67,145$.

69 See National Mediator Accreditation System Standards (July 2015), standard 9.

70 Sourdin, Alternative Dispute Resolution, above n 5, 479; Anthony A Nolan and Michael O'Brien, 'Confidentiality in Mediations - A Work in Progress' (unpublished paper, 12 May 2010).

71 See Evidence Act 2008 (Vic) s 131.

72 For example, Anthony A Nolan and Michael O'Brien, 'Confidentiality in Mediations: A Work in Progress' (unpublished paper, 12 May 2010).

73 Tom Altobelli and Diana Bryant, 'Has Confidentiality in Family Dispute Resolution Reached its Use-by Date?' in Daryl J Higgins (ed), Families, Policy and the Law (Australian Institute of Family Studies, 2014) 195. Ibid. 


\section{Voluntariness and Good Faith}

Court-connected mediation is mandatory, which may be problematic for those mediators who are ethically committed to the purist notions of mediation theory in which voluntary participation by disputants is a core component. Facilitative ADR processes are built on the premises of free participation by disputants, as well as their empowerment in and ownership of their dispute and, ${ }^{75}$ importantly, their self-determination in its resolution. ${ }^{76}$ Mediation theory is based on a non-coercive discourse grounded on consensus and personal autonomy. These principles appear to conflict with the statutory imperatives that require parties to participate in ADR (and particularly mediation). ${ }^{77}$ Interestingly though, some authors have noted that where ADR is an option (that is, it is not mandated) there are low uptake rates, ${ }^{78}$ although it is suggested by Boulle that where this happens the matter is probably not suitable for settlement. ${ }^{79}$

We recognise the inherent tension between classic mediation theory and mediation practice derived from the institutionalisation of the process. The conundrum presented by the definitional requirement of voluntary participation of the parties on the one hand, and the compulsion to attend mediation in civil disputing and under the FLA is difficult to resolve.

The interconnection between mediation and the legal system has meant that the theoretical framework upon which the mediation movement is based is increasingly influencing both the legal culture and a range of legal processes in most Australian jurisdictions. The Australian Law Reform Commission (ALRC) pointed out in 1999 that "processes such as case management, court or tribunal connected ADR processes and discretionary rules of evidence and procedure have modified adversarial

$75 \quad$ Nils Christie, 'Conflicts as Property' (1977) 17 British Journal of Criminology 1; Boulle, above n 2, 63 .

76 See Nancy A Welsh, 'Reconciling Self-Determination, Coercion, and Settlement in Court-Connected Mediation' in Jay Folberg, Ann L Milne and Peter Salem (eds), Divorce and Family Mediation: Models, Techniques, and Applications (Guilford Publications, 2004) 420.

77 The following cases are instances where courts have used their discretion to mandate mediation without consent of the parties to the dispute: Sellar v Lasotav Pty Ltd [2008] FCA 1766; Waterhouse v Perkins [2001] NSWSC 13; Idoport Pty Ltd $v$ NAB Ltd [2001] NSWSC 427; Dickerson v Brown [2001] NSWSC 714. These cases illustrate the point that mediation theory and practice differ, thereby creating ethical issues for mediators.

78 Astor and Chinkin, above n 14, 270. National Alternative Dispute Resolution Advisory Council (NADRAC), A Framework for ADR Standards, Report to the Commonwealth Attorney-General (April 2001) 24 [2.59] reports that efforts to estimate 'the level of service demand and usage is ... problematic'.

79 John Wade, 'Don't Waste my Time on Negotiation and Mediation: This Dispute Needs a Judge' (2001) 18 Mediation Quarterly 259, 272, cited in Cameron Green, 'ADR: Where Did the "Alternative" Go? Why Mediation Should Not Be a Mandatory Step in the Litigation Process' (2010) 12(3) Australian Alternative Dispute Resolution Bulletin 2, 3. 
features of the system' ${ }^{80}$ But does the movement of ideas, behaviours and mindsets travel both ways? What if adversarial processes and practices inappropriately influence $\mathrm{ADR}$, thereby detracting from the potential benefits of such processes? For example, FDR practitioners have the power to certify that parties who attend and make a 'genuine effort' to reach agreement have complied with the legislative requirement to use mediation as a dispute management process of first resort. ${ }^{81}$ When does this obligation create the potential for 'fishing expeditions' and or legal strategies? ${ }^{82}$

How do mediators deal with parties or their representatives who misuse mediations? Dearlove describes situations on point as follows: failure to attend mediation; using the process to score a point in litigation, posturing and using power plays to advance ego-centred directions, withholding information unnecessarily, using mediation to ramp up costs and to delay resolution of the dispute. ${ }^{83}$

We suggest the incorporation of a Practice Standard to guide mediators to focus parties, and their legal representatives, when the mediator believes, on reasonable grounds, that one or more stakeholders lacks 'good faith', ${ }^{84}$ is not making a 'genuine effort' to participate in a collaborative negotiation, or when the process may be at risk of being abused, used as a tactic, or where adversarialism compromises the interest based premise of the process. It would be useful in this instance for the Practice Standard to define and address 'good faith' and 'genuine effort'.

Sourdin comments that the good faith requirement in the ADR context is hard to define. It is both an evolving concept, and a fluid one. The notion of what constitutes good faith and conversely what is regarded as bad faith is subjective, hard to gauge, and fraught with issues, particularly in the court connected milieu. In both the FDR and the civil mediation environment, parties are required to attend mediation. The mediation room may constitute the process of first resort for disputants. Mediators need to grapple with the dissonance from purist mediation theory in order to evaluate what represents a reasonable display of good and bad faith. Whilst recent case law in various Australian jurisdictions may provide some direction, each case has its own indicators and requires consideration on its unique facts. ${ }^{85}$

80 Australian Law Reform Commission, Managing Justice: Review of the Federal Civil Justice System (2000) 108.

81 See Family Law Act (Cth) 1975 s 601.

82 See PA Bergin, Judicial Mediation in Australia (Paper presented at the National Judicial College, Beijing, 25-28 April 2011) $2<$ www.supremecourt.lawlink.nsw. gov.au/agdbasev7wr/supremecourt/documents/pdf/bergin250411.pdf>.

83 Grant Dearlove, 'Sanctions for the Recalcitrant Lawyer and Party' (1999) 2(3) Australian Alternative Dispute Resolution Bulletin <epublications.bond.edu.au/ $\mathrm{adr} / \mathrm{vol} 2 / \mathrm{iss} 3 / 1>$.

84 See Tania Sourdin, 'Good Faith, Bad Faith? Making an Effort in Dispute Resolution' (2012) Good Faith Paper $1<w w w . c i v i l j u s t i c e . i n f o / g o o d f / 1>$. 
Mediators need to remind stakeholders that they are required by the legislative regime to make a 'genuine effort' to resolve issues during the family dispute resolution process. ${ }^{86}$ Similarly, mediators in court connected civil disputes should be focused on signalling to parties and their legal representatives the importance of adhering to the over-arching obligations contained in the Civil Procedure Act 2010 (Vic). ${ }^{87}$ Stakeholders need to demonstrate genuine commitment to narrowing the issues in dispute and, to the just, timely and efficient resolution of the dispute. ${ }^{88}$

Notably, the Civil Dispute Resolution Act 2011 (Cth) which requires parties to undertake 'genuine steps' to resolve disputes before instituting proceedings in a court does not apply to proceedings under the FLA.

\section{ADR Within a Legal System and The Public Good}

Waldman described the intersection between mediator practices and social norms, ${ }^{89}$ referencing Fuller when she explained the norm generating effect of the Folberg and Taylor classic mediation model.$^{90}$ This Part of the article centres on a key question arising from Waldman's assertion. Are mediators 'doing good'? Is their work assisting stakeholders? Or are they mere adjuncts of a court workflow agenda driven by governments and their agents?

The processes are now an indispensable public service, part of the administration of justice in Australia. ${ }^{91}$ We postulate that these processes form part of a public system that promotes social harmony and enables the orderly administration of society by way of resolving civil disputes and family disputes in mediation. ${ }^{92}$

However, the notion of ADR within a legal system may create the potential and perception that mediators/practitioners can be acting as agents of the court. This agency can manifest in a variety of ways that may threaten process, agreements, outcomes and roles. The compromise may be subtle, inadvertent or overt and intentional. Additionally, the interface with the legal system can have an even darker side, which may challenge stakeholders' ethics. We consider some of these impacts below when we discuss adversarialism, coercion and manipulation of the process.

The connection between mediation and the legal system has meant that adversarial processes and practices may inappropriately influence $\mathrm{ADR}$, thereby detracting from the potential benefits of such processes

$86 \quad$ Family Law Act 1975 (Cth) s 60I.

87 See Civil Procedure Act 2010 (Vic) ss 16-26.

88 See Harman, above $\mathrm{n} 1$.

89 See Waldman, above n 12.

90 Ibid 719.

91 See PA Samuelson, Economics: An Introductory Analysis (McGraw-Hill Book Company, 7th ed, 1967) 47. See Civil Procedure Act 2010 (Vic) s 9(1)(b).

92 See The Hon T F Bathurst AC, Chief Justice of New South Wales, Opening of Law Term Address 'Reformulating Reform: Courts and the Public Good', 4 February 2015. 
through mindsets and tactics. This tension around agency can be increased if success is measured by number of agreements. Practitioners make decisions around proceeding in light of judgements of suitability and capacity. However, pressure to provide processes cognisant of the lack of appropriate, affordable, and timely alternatives for clients may affect judgements. The norms generated by submerging mediation within a legal system need to be recognised..$^{93}$ Rundle observes that it is important for court-connected mediation to set out the goals of mediation programs. ${ }^{94}$ We argue that this aim may not go far enough. Whilst it may be useful to define whether mediation is a case-management tool or premised on traditional notions of party autonomy and empowerment, ${ }^{95}$ process mission statements go only so far to assist mediators in dealing with ethical issues. Reflective practice, debriefing and peer review and support may be better suited to assist mediators in managing ethical conundrums.

Court-connected mediation in civil disputes and court-related FDR add to the efficiency of the justice system. They promote justice inside and external to the formal justice system. They are of public benefit and are valuable components of an effective justice system. These values should underpin and resonate throughout mediator ethics.

The National Mediator Accreditation System (NMAS) Standards (1 July 2015) acknowledge the diversity of mediation practice in Australia. ${ }^{96}$ Yet the NMAS Standards may not address core components in the range of processes that may require recognition. We raise the need to add to the Practice Standards (specifically in mediation in court-connected matters), reflecting the need for mediators to be aware of, and acknowledge their public role in these processes.

\section{Procedural Justice}

Concerns have been raised about mediation and the notion of achieving procedural justice for disputants. ${ }^{97}$ Mediations are not open to review. They are private and confidential, as far as the law allows, and therefore are not open to public scrutiny. There are no clear 'rules' to follow. The law is not applied to the facts. The doctrine of precedent is not applied in ADR which raises the ethical conundrum around consistency in process, experience and outcome.

Whilst legal actors may perceive procedural justice as equating with fairness when due process is afforded by adhering to substantive and procedural rules, Tyler identifies four factors that represent fairness for

$93 \quad$ See Waldman, above n 12.

94 Olivia Rundle, 'Barking Dogs: Lawyer Attitudes Towards Direct Disputant Participation in Court-Connected Mediation of General Civil Cases' (2008) 8 Queensland University of Technology Law and Justice Journal 77, 91.

95 Ibid.

96 See Part 1 - Introduction, Purpose.

97 See Rebecca Hollander-Blumoff and Tom R Tyler, 'Procedural Justice and the Rule of Law: Fostering Legitimacy in Alternative Dispute Resolution' (2011) 1 Journal of Dispute Resolution 1. 
litigants and the public: neutrality, respect, participation and trustworthiness. ${ }^{98}$ According to Lind and Tyler, 'fair' procedures prompt stakeholder compliance with outcomes, and help to legitimise the decision making process. ${ }^{99}$

NADRAC has emphasised the goal of procedural fairness in ADR processes in its 'Framework Standards'. ${ }^{100}$

Procedural justice in the context of FDR and the civil claims program in the Magistrates' Court may be apparent, because mediations are 'process driven', although generally fluid and flexible. ${ }^{101}$ Tyler and Lind's indicators of procedural fairness can generally be made out. ${ }^{102}$ Disputants are given an opportunity to voice their concerns in an atmosphere of civility, respect and dignity. The process is explained to disputants, in a way that they are able to understand. Disputants see the mediator as unbiased and trustworthy.

Mediation research points to what Bush and Folger describe as mediation's 'satisfaction story'. ${ }^{103}$ Notably, the Australian Law Reform Commission has stated that when parties are compelled to participate in $\mathrm{ADR}$, in particular, mediation such as FDR, ${ }^{104}$ this encouragement can amount to pressure to settle. ${ }^{105}$

Nevertheless, the issue of agreements within the context of a legal framework is a significant ethical issue for mediators. In mediation processes there is often a subtle or not-so-subtle impetus or pressure to

98 Tom R Tyler, 'Citizen Discontent with Legal Procedures: A Social Science Perspective on Civil Procedure Reform' (1997) 45 American Journal of Contemporary Law 871, 887.

99 Elizabeth Mullen and Linda J Skitka, 'When Outcomes Prompt Criticism of Procedures: An Analysis of the Rodney King Case' (2006) 6 Analyses of Social Issues and Public Policy 1, 2 citing E Allan Lind and Tom R Tyler, The Social Psychology of Procedural Justice (Plenum Press, 1988).

100 NADRAC, A Framework for ADR Standards, above n 78, 13-14 [2.3].

101 For example, in the mediation process, if and when to break from joint session into separate session.

102 See E Allan Lind and Tom R Tyler, The Social Psychology of Procedural Justice (Plenum Press, 1988).

103 See Timothy Hedeen, 'Coercion and Self-determination in Court-connected Mediation: All Mediations are Voluntary, But Some are More Voluntary Than Others' (2005) 26(3) Justice System Journal Denver 273.

104 See Family Law Act 1975 (Cth) s 60I:

(1) The object of this section is to ensure that all persons who have a dispute about matters that may be dealt with by an order under this Part (a Part VII order) make a genuine effort to resolve that dispute by family dispute resolution before the Part VII order is applied for....

(7) Subject to subsection (9), a court exercising jurisdiction under this Act must not hear an application for a Part VII order in relation to a child unless the applicant files in the court a certificate given to the applicant by a family dispute resolution practitioner under subsection (8). The certificate must be filed with the application for the Part VII order.

See also Mark J Rankin, 'Settlement at All Costs: The High Price of an Inexpensive Resolution?' (2009) 20 Australasian Dispute Resolution Journal 153, 154.

105 'Managing Justice: Review of the Federal Civil Justice System' (Discussion Paper No 62, Australian Law Reform Commission, 1999) 28.76-28.78. 
reach an agreement. Sometimes this is linked to the notion of a successful outcome or even with key performance indicators for mediators. This may come from the participants' interests, financial pressures, legal representation, the mediator themselves, ${ }^{106}$ or simply operating within a parallel and overlapping system cast by the shadow of the law. In FDR, practitioners have a duty of care to ensure that consideration is given to reality-testing and ensuring durability and sustainability of any potential agreements. In the civil mediation context, there is a paucity of case law setting out any such duty.

It has been suggested that the focus on settlement in mediation compromises procedural justice. Rankin remarks that 'a fundamental jurisprudential dilemma: in focusing on settlement "at all costs", has mediation that is court-connected and operates under the shadow of the law side-stepped justice in the process? ${ }^{107}$ Rankin posits a somewhat extreme position by referring to 'settlement at all costs'. ${ }^{108}$ This notwithstanding, how far should mediators go to facilitate resolution? Where is the ethical line in the sand dividing coercion from encouragement? ${ }^{109}$ How does the pressure to settle sit with the core mediation requirements of party freedom, autonomy and self-determination? ${ }^{110}$ Importantly, how can this ethical conundrum be dealt with by mediators practising in the court-connected, case management environment, where French CJ has remarked that disputes should be settled in a 'just, speedy and inexpensive manner'?111

\section{ConcLusion}

'ADR is only as good as its practitioners'. ${ }^{112}$ The Hon Michael Kirby points out that the success of ADR processes hinges upon the integrity, skills and training of the relevant personnel. Mediator integrity, training and skills are essential to the success of processes, and to the perception of mediation's potency. Civil claims mediation and FDR provide a public service and promote the public good by providing opportunities for parties to participate in a process where the process itself is not the punishment. ${ }^{113}$

106 Timothy Hedeen, 'Coercion and Self-Determination in Court-Connected Mediation: All Mediations are Voluntary, but Some are More Voluntary than Others' (2005) 26 Justice System Journal Denver 273.

107 Mark J Rankin, 'Settlement at All Cost: The High Price of an Inexpensive Resolution?' (2009) 20 Australasian Dispute Resolution Journal 153, 155.

108 Ibid.

109 Tapoohi v Lewenberg [2003] VSC 410.

110 John Wade, 'Liability of Mediators for Pressure, Drafting and Advice' (2004) 6(97) Australian Alternative Dispute Resolution Bulletin 131.

111 Chief Justice RS French, 'State of the Judicature' (2010) 84 Australian Law Journal 310, 316 quoting Fix-Fierro, Courts, Justice \& Efficiency-A Socio-legal Study of Economics Rationality in Adjudication (2003) 8.

112 Michael Kirby, 'Alternative Dispute Resolution-A Hard-Nosed View of Its Strengths and Limitations' (Paper presented at the Institute of Arbitrators and Mediators Australia, South Australian Chapter, Adelaide, 29 July 2009).

113 See Malcolm M Feely, The Process is the Punishment (Russell Sage Foundation, 1992). 
Mediator ethical conundrums can be managed, explored and the impacts minimised, by shining an ethical lens on mediation practices through ongoing supervision processes focusing on self-awareness, self-reflection and conscious development of mediator skills. The goal is that these processes progress mediation towards higher levels of ethical practice, notwithstanding inherent dilemmas around transparency, voluntariness, pressures to settle, consistency and the 'shadow of the law'.

Complexities remain when addressing ethical issues in practice. Despite underlying requirements for open and honest self-reflection, insight, humility and courage, ethical issues usually occur in a complicated prism. There is a need to explore different ethical models, rather than view frameworks in isolation.

Menkel Meadow draws together the interlocking ideas of striving to attain justice within a legal system whilst catering to the needs of the human condition. She remarked:

Over time, purist mediation models have evolved with social systems through practice developments, practice contexts, being located in court systems and as mediators borrow from the knowledge, skill and practice of their primary backgrounds (including social sciences and law qualifications). ${ }^{114}$

Since the birth of mediation in the neighbourhood context, it has morphed into a process that is interconnected to the civil justice system and the family law framework. The transition from an alternative to an entrenched and professionalised process of dispute resolution has changed several elements of the orthodox prototype. Further, the changes may pose intractable ethical challenges for mediators. We call for regulators and trainers to acknowledge ethical tensions that persist in mediation practice and to consider alterations to training, standards and codes of practice that will accommodate and enhance the evolution of 'best practice' clinical delivery of services in the field.

114 Carrie Menkel-Meadow, 'From Legal Disputes to Conflict Resolution and Human Problem Solving: Legal Dispute Resolution in a Multidisciplinary Context' (2004) 54 Journal of Legal Education 6. 